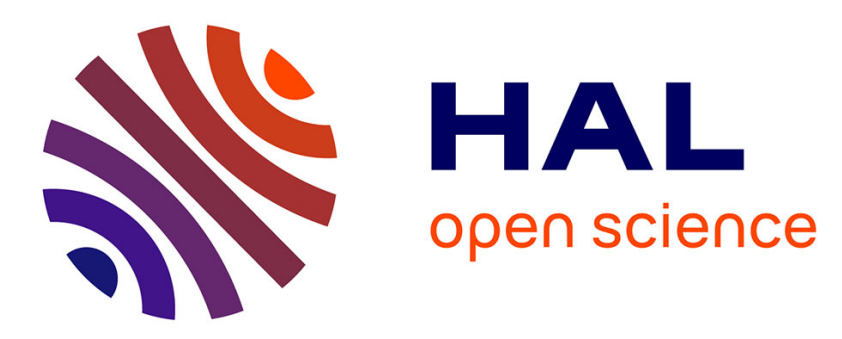

\title{
Damage induced to DNA by low-energy (0-30 eV) electrons under vacuum and atmospheric conditions.
}

Emilie Brun, Pierre Cloutier, Cécile Sicard-Roselli, Michel Fromm, Léon Sanche

\section{- To cite this version:}

Emilie Brun, Pierre Cloutier, Cécile Sicard-Roselli, Michel Fromm, Léon Sanche. Damage induced to DNA by low-energy (0-30 eV) electrons under vacuum and atmospheric conditions.. Journal of Physical Chemistry B, 2009, 113 (29), pp.10008-13. 10.1021/jp902540k . hal-00515989

\section{HAL Id: hal-00515989 \\ https://hal.science/hal-00515989}

Submitted on 8 Sep 2010

HAL is a multi-disciplinary open access archive for the deposit and dissemination of scientific research documents, whether they are published or not. The documents may come from teaching and research institutions in France or abroad, or from public or private research centers.
L'archive ouverte pluridisciplinaire HAL, est destinée au dépôt et à la diffusion de documents scientifiques de niveau recherche, publiés ou non, émanant des établissements d'enseignement et de recherche français ou étrangers, des laboratoires publics ou privés. 


\title{
Damage Induced to DNA by Low-Energy $(0-30 \mathrm{eV})$ Electrons under Vacuum and Atmospheric Conditions
}

\author{
Émilie Brun, ${ }^{\dagger}$ Pierre Cloutier, ${ }^{\ddagger}$ Cécile Sicard-Roselli, ${ }^{\dagger}$ Michel Fromm, ${ }^{\S}$ and Léon Sanche ${ }^{*, \dagger, ;}$ \\ Laboratoire de Chimie Physique, CNRS UMR 8000, Université Paris-Sud 11, Bât. 350, \\ 91405 Orsay Cedex, France, Groupe de recherche en sciences des radiations, Faculté de médecine et des \\ sciences de la santé, Université de Sherbrooke, Sherbrooke, Quebec J1H 5N4, Canada, Laboratoire de \\ Microanalyses Nucléaires - Alain Chambaudet, UMR CEA E4 Université de Franche-Comté, \\ Besançon Cedex, France
}

Received: March 20, 2009

\begin{abstract}
In this study, we show that it is possible to obtain data on DNA damage induced by low-energy $(0-30 \mathrm{eV})$ electrons under atmospheric conditions. Five monolayer films of plasmid DNA (3197 base pairs) deposited on glass and gold substrates are irradiated with $1.5 \mathrm{keV}$ X-rays in ultrahigh vacuum and under atmospheric conditions. The total damage is analyzed by agarose gel electrophoresis. The damage produced on the glass substrate is attributed to energy absorption from X-rays, whereas that produced on the gold substrate arises from energy absorption from both the X-ray beam and secondary electrons emitted from the gold surface. By analysis of the energy of these secondary electrons, $96 \%$ are found to have energies below $30 \mathrm{eV}$ with a distribution peaking at $1.4 \mathrm{eV}$. The differences in damage yields recorded with the gold and glass substrates is therefore essentially attributed to the interaction of low-energy electrons with DNA under vacuum and hydrated conditions. From these results, the $G$ values for low-energy electrons are determined to be four and six strand breaks per $100 \mathrm{eV}$, respectively.
\end{abstract}

\section{Introduction}

Processes induced by low-energy electrons (LEEs) in biomolecules have attracted considerable attention. ${ }^{1-3}$ The major impetus for this research has arisen mainly from their important role in radiobiology. ${ }^{4}$ Such electrons are produced in large numbers by ionizing radiation and may be responsible for much of the subsequent damage inflicted to molecules found in biological cells. ${ }^{5-7}$

Our present knowledge of LEE-biomolecule interactions arises from both theoretical and experimental investigations. The experiments that led to our comprehension of the mechanisms responsible for the fragmentation and modification of biomolecules by LEE impact were performed either in the gas phase or with molecular solid films, both under high or ultrahigh vacuum (UHV) conditions. ${ }^{8}$ Molecules that could be evaporated in a vacuum environment without decomposition have usually been studied as gases, but some studies have also been reported on solid molecular films. ${ }^{8}$ Those that could not be evaporated without fragmentation were investigated as solid films ${ }^{8}$ and, more recently, as aggregates in cooled He jets. ${ }^{9}$ Even though these investigations were necessary to isolate the basic LEE-biomolecule mechanisms responsible for damage, they were not performed under conditions that take into account the hydrated and aerobic environment of the cell. It is now well established that the processes induced by electron impact on a molecule are highly dependent on its environment. ${ }^{4}$ It is therefore crucial, if we are to apply our knowledge of LEEbiomolecule interactions to practical problems in radiation

* To whom correspondence should be addressed. Phone number: (819) 346-1110, poste 14678. Fax number: (819) 564-5442. E-mail address: Leon.Sanche@USherbrooke.ca.

${ }^{\dagger}$ Université Paris-Sud 11.

* Université de Sherbrooke.

$\S$ Université de Franche-Comté. protection and therapy, to show how the fundamental mechanisms derived from gaseous and thin film studies are affected and modified under the hydrated and aerobic environment of the cell.

It is particularly important to perform experiments under such conditions with the DNA molecule, since the detrimental biological effects of ionizing radiation are usually caused by damage to the genome. ${ }^{10}$ The characteristics of the molecule in its natural environment may be quite different from those under UHV conditions. In the latter conditions, DNA retains only structural $\mathrm{H}_{2} \mathrm{O}$ (i.e., two water molecules per nucleotide) within its structure and thus adopts the compressed A-form. ${ }^{11}$ On the other hand, cellular DNA is mainly in the B-form and contains about 20 bound water molecules per nucleotide in the first $(\Gamma$ $<9$; $\Gamma$ is defined as the number of water molecules per nucleotide) and second $(9<\Gamma<20)$ layers of hydration..$^{12,13}$ The first layer consists of contiguous surface water, while the second layer represents amorphous water. Radiolysis of water produces electrons and holes. Electrons readily transfer from both the first and second layers of water to DNA, but only holes of the first hydration layer can transfer to DNA, while holes of the second hydration layer react with water to form hydroxyl radicals, which subsequently react with DNA. ${ }^{14,15}$ Accordingly, hydration levels affect the yields of single (SSB) and double (DSB) strand breaks, unaltered nucleobase release, and base damage in irradiated DNA. ${ }^{16-20}$

The study of LEE interactions with biomolecules in their natural environment poses a formidable experimental challenge. How can we develop a source of LEE capable of interacting with large biomolecules under hydrated and aerobic conditions similar to those in biological cells? Obviously, there is a considerable amount of development to be made to eventually be able to completely distinguish in irradiated biological systems the processes induced by LEE from those caused by other 
secondary radiolytic products. The work presented in this paper constitutes a first attempt to develop a method to achieve this goal. More specifically, we show that it is possible to obtain data on LEE damage induced to a large biomolecule (i.e., DNA), held under atmospheric conditions. By performing exactly the same experiments under vacuum and atmospheric conditions, we show that insight can be gained on the modifications introduced by a hydrated environment.

The proposed method is based on the technique developed by Cai et al. ${ }^{21}$ to investigate DNA damage resulting from secondary electron (SE) emission from a metal surface exposed to soft X-rays. These authors exposed thick and thin films of pGEM-3Zf(-) plasmid DNA deposited on a tantalum foil to soft X-rays of effective energy of $14.8 \mathrm{keV}$ for various times in air under controlled relative humidities $(\Gamma \approx 6$ and 21$)$. In the thick film, DNA damage was induced chiefly by X-ray photons whereas in the thin film, X-ray-induced SEs emitted from the tantalum resulted in a substantial increase in DNA damage. With $14.8 \mathrm{keV}$ mean energy photons incident on a metal, the SEs emitted have wide energy distribution. For example, in the case of tantalum, the quantum yield is 0.009 and 0.015 electron/photon for $0-10 \mathrm{eV}$ electrons and highenergy ones, respectively. However, as the primary photon energy is lowered, the emitted SE distribution shifts to lower energies. As shown in this paper, below about $1.5 \mathrm{keV}$ incident photon energy, the SE distribution emitted from a gold surface consists essentially of LEEs. If operated in air, such a source could supply LEEs to any biological target deposited on a gold substrate.

Owing to the high scattering cross sections of low-energy photons from ambient molecules, ${ }^{22} 1.5 \mathrm{keV} \mathrm{X}$-ray sources normally operate under vacuum. We therefore developed an apparatus, described herein, suitable for low-energy X-ray irradiation of thin films in ambient or controlled atmosphere. The construction of the X-ray source is based on the original design of Neary et al. used for plant cell irradiation. ${ }^{23,24}$ The apparatus is equipped with an $\mathrm{Al} \mathrm{K \alpha} \mathrm{X}$-ray source, but the metal target can be replaced for X-ray emission at other characteristic energies. To delineate the portion of DNA damage caused by $\mathrm{X}$-rays and that arising from LEE interactions, we performed experiments with films deposited on an insulator and the electron-emitting gold surface under different environmental conditions. The damage to DNA induced by LEEs measured under atmospheric conditions and the corresponding $G$ values are compared with the results obtained under vacuum.

\section{Experimental Methods}

DNA Preparation and Manipulation. pGEM-3Zf(-) plasmid DNA (3197 base pairs, Promega) was extracted from Escherichia coli $\mathrm{DH}_{5 \alpha}$ and purified with the QIAfilter Plasmid Giga Kit (Qiagen). Agarose gel electrophoresis showed that 95\% of the extracted plasmid was in the supercoiled form. The DNA pellet was redissolved in TE buffer (10 mM Tris, 1 mM EDTA, pH 8). DNA was then desalted using Sephadex G-50 purification. ${ }^{25}$ Briefly, a homemade microcolumn was filled with Sephadex G-50 resin on a glass beads bed. After equilibration and washes with $\operatorname{ddH}_{2} \mathrm{O}, 5 \mu \mathrm{g}$ of DNA was deposited per column and eluted by centrifugation.

The DNA concentration was obtained by measuring its absorption at $260 \mathrm{~nm}$, taking a molar absorption coefficient of $5.3 \times 10^{7} \mathrm{~L} \cdot \mathrm{mol}^{-1} \cdot \mathrm{cm}^{-1}$ at $\mathrm{pH} 7.0{ }^{26}$ The stock solution concentration was approximatively $50 \mathrm{ng} \cdot \mu \mathrm{L}^{-1}$. DNA purity was checked by recording the ratio between absorbances at 260

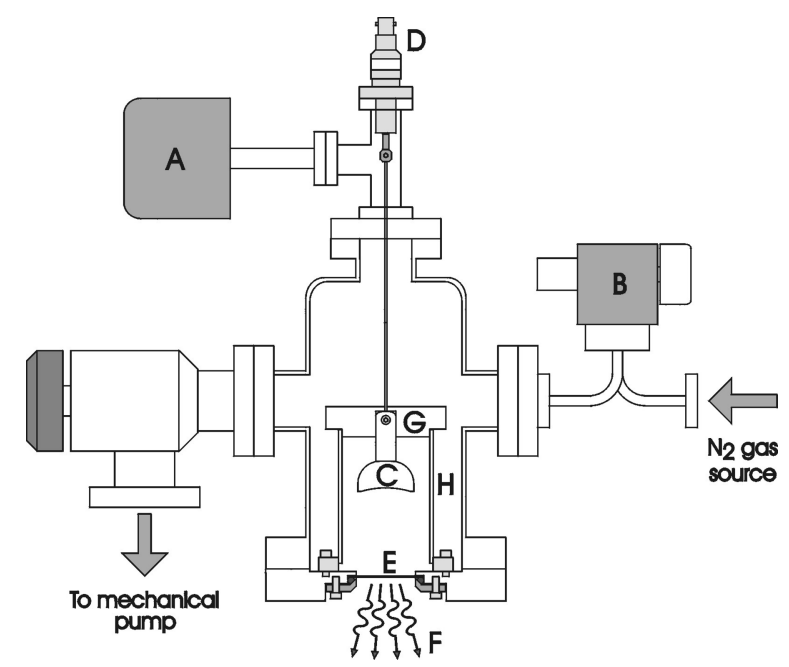

Figure 1. Schematic overview of the type of apparatus used to irradiate samples with $1.5 \mathrm{keV} \mathrm{Al} \mathrm{K} \alpha \mathrm{X}$-ray photons under atmospheric conditions: (A) baratron, (B) adjustable leak valve, (C) concave aluminum cathod, (D) high voltage electric feedthrough, (E) aluminum foil, (F) atmosphere, (G) glass-ceramic support, $(\mathrm{H})$ quartz tube.

and $280 \mathrm{~nm} \cdot{ }^{27-29}$ It was found to be 1.98 , which testifies of the absence of protein.

Sample Preparation. DNA (260 ng) in $10 \mu \mathrm{L}$ of ultrapure $\mathrm{H}_{2} \mathrm{O}$ was deposited onto cleaned glass or gold substrates (Arrandee comp.). Samples were frozen at $-130{ }^{\circ} \mathrm{C}$ for $10 \mathrm{~min}$ and then lyophilized with a hydrocarbon-free sorption pump under a pressure of $3 \mathrm{mTorr}$ for $1 \mathrm{~h}$. With a density of 1.7 $\mathrm{g} \cdot \mathrm{cm}^{-3}$ and a diameter of $4.4 \pm 0.2 \mathrm{~mm}$, the DNA film thickness was estimated to be $10 \mathrm{~nm}$ or 5 monolayers (ML).

Irradiation under Ultrahigh Vacuum. The lyophilized samples were transferred to a load lock vacuum chamber, which reached a pressure of $10^{-7}$ Torr after $1 \mathrm{~h}$. This chamber is evacuated by an oil-free turbomolecular pump and connected to an UHV chamber $\left(3 \times 10^{-10}\right.$ Torr $)$ via a gate valve. It is equipped with a sample holder connected to a mechanical feedthrough, which allows transfer of the sample, via the gate valve, to another target holder located in the UHV chamber. A detailed description and a schematic diagram of the load lock arrangement can be found in ref 30 . With this system, it is possible to introduce the sample into the UHV chamber for $\mathrm{X}$-ray exposure without breaking the $3 \times 10^{-10}$ Torr vacuum. $\mathrm{Al} \mathrm{K} \alpha \mathrm{X}$-rays $(1.5 \mathrm{keV})$ were produced using a PHI model 04548 dual anode X-ray source (Perkin-Elmer) with an aluminum target. The anode voltage and emission current were fixed at 4 $\mathrm{kV}$ and $1.1 \mathrm{~mA}$ respectively. In these conditions, the incident fluence rate of photons has been estimated to be $1.14 \times 10^{10}$ photons $\cdot \mathrm{cm}^{-2} \cdot \mathrm{s}^{-1}$. ${ }^{31}$ The incidence of the X-rays was at $70^{\circ}$ with respect to the normal target surface.

Irradiation under Atmospheric Conditions. The lyophilized samples were exposed to the $\mathrm{Al} \mathrm{K \alpha} \mathrm{X}$-rays produced, under atmospheric conditions, from a cold-cathode transmission target $\mathrm{X}$-ray tube. A cross-sectional view of the apparatus is shown in Figure 1. It is composed of a stainless steel chamber to which are connected a mechanical pump, a baratron (A) and an adjustable leak valve (B) joined to a high pressure $\mathrm{N}_{2}$ gas source. With this arrangement, it is possible to maintain a stabilized $\mathrm{N}_{2}$ pressure of about $20 \mathrm{mTorr}$ in the chamber. Under normal running conditions, a potential of $3.3 \mathrm{kV}$ is applied to a concave aluminum cathode (C) through a high-voltage electrical feedthrough (D). A plasma discharge of $4.0 \mathrm{~mA}$ is produced between this cathode and an $\mathrm{Al}$ foil target (E). The discharge electron current is controlled by the stabilized circulation of 
the $\mathrm{N}_{2}$ gas with the leak valve. The cathode-target distance is $54 \mathrm{~mm}$, and the diameter of each is $35 \mathrm{~mm}$. Electrons from the discharge are incident on the thin foil target $(10.5 \mu \mathrm{m}$ thick) where they ionize $\mathrm{Al}$ atoms. The characteristic $\mathrm{K}$ X-rays (1.5 $\mathrm{keV}$ ) produced by electron impact traverse the target and emerge in the atmosphere side (F). Due to their low energy, incident electrons produce very low bremsstrahlung background intensity in the forward direction. ${ }^{23}$ Since the Al foil target serves also as the vacuum window, it is supported on a stainless steel grid that has a $45 \%$ transparency ratio (wire diameter $=0.25 \mathrm{~mm}$, $13 \times 13$ wires/cm). To prevent discharge between the cathode and the chamber walls, the former is fixed in a machineable glass-ceramic (Macor) support $(\mathrm{G})$ which is placed as a cap on a long quartz tube $(\mathrm{H})$.

Special attention has been paid in the design of this apparatus so as to be able to place the X-ray source close to thin films of DNA to avoid too much photon absorption by the atmosphere during irradiation. With such a feature, it is possible to irradiate biological molecules or cells directly in an atmosphere where humidity conditions can be controlled. In this work, lyophilized DNA samples were fixed on a target holder under laboratory humidity conditions (65\%). The distance between Al foil and the sample was $0.9 \mathrm{~cm}$. Taking the mass attenuation coefficient of air $\left(\mu / \rho=1.191 \times 10^{3} \mathrm{~cm}^{2} \cdot \mathrm{g}^{-1}\right)$ and its density $(\rho=1.205$ $\left.\times 10^{-3} \mathrm{~g} \cdot \mathrm{cm}^{-3}\right)$ and using the exponential attenuation law $I_{\mathrm{t}}=$ $I_{\mathrm{o}} \mathrm{e}^{(-\mu / \rho \cdot \rho \cdot x)}$, one can calculate a $72 \%$ photon beam absorption in air. Closer distances resulted in sample heating.

Dosimetry. Dosimetry was done using Gafchromic HD-810 radiochromatic dosimetry film (ISP Technologies Inc., Wayne, NJ) as described elsewhere. ${ }^{31}$ After exposure to radiation, the film samples were stored in the dark for $48 \mathrm{~h}$ at room temperature and then scanned with a HP ScanJet 4400C. The output resolution was $300 \mathrm{dpi}$, the output type was true color, and the intelligent scanning technology was turned off. Blue channel images were analyzed with ImageJ software. ${ }^{32}$ The absorbance was defined as $\log _{10}\left(I_{0} / I\right)$ where $I_{0}$ and $I$ are the mean values resulting from the ImageJ color analysis histograms for nonexposed and exposed zones of the samples, respectively. Calibration of the sensitivity of the film was obtained by irradiating film samples with $14.8 \mathrm{keV}$ X-rays generated with a superficial therapy X-ray unit (Pantak Therapax 3 series) at the Université de Sherbrooke Hospital Center $(0.4 \mathrm{~mm}$ aluminum filter, $30 \mathrm{kV}$ potential energy, $7.6 \mathrm{~mA}$ filament current). The absorbed dose rate in water, according to the ionization chamber measurement, was $2.1 \mathrm{~Gy} \cdot \mathrm{min}^{-1}$. A linear relationship between $\log _{10}\left(I_{0} / I\right)$ and the dose was obtained in the range 0-100 Gy. Because the film response is energy-dependent, some corrections were added; in particular, the ratio of mass energy absorption coefficients $\left(\mu_{\mathrm{en}} / \rho\right)$ between the active layer of the film and water was taken into account. For the active layer, $\left(\mu_{\mathrm{en}} / \rho\right)$ was obtained by simple addition using $\mu_{\mathrm{en}} / \rho=\sum_{i} f_{i}\left(\mu_{\mathrm{en}} /\right.$ $\rho)_{i}$ where $f_{i}$, the elemental weight fractions, can be found in ref 31. Because the water content in the film has an effect on its response to $1.5 \mathrm{keV} \mathrm{X-rays,} \mathrm{it} \mathrm{was} \mathrm{important} \mathrm{to} \mathrm{use} \mathrm{the}$ appropriate elemental composition to calculate the mass attenuation coefficients. The ratio $\left(\mu_{\mathrm{en}} / \rho\right)_{\mathrm{AL}} /\left(\mu_{\mathrm{en}} / \rho\right)_{\text {water }}$ at $15 \mathrm{keV}$ was found to be 0.668 , whereas it was 0.724 in air and 0.676 in vacuum at $1.5 \mathrm{keV}$. Thus, the proportionality factors between $\log _{10}\left(I_{0} / I\right)$ and the equivalent dose absorbed in water were found to be $2.82 \times 10^{-4} \mathrm{~Gy}^{-1}$ in air and $2.87 \times 10^{-4} \mathrm{~Gy}^{-1}$ in vacuum.

To obtain the dose rates of the different irradiation sources, the corrected doses given by Gafchromic analysis were plotted versus the exposition times, resulting in slopes of 52.7 and 129.2 $\mathrm{Gy} \cdot \mathrm{min}^{-1}$, respectively, for the cold-cathode X-ray tube (in

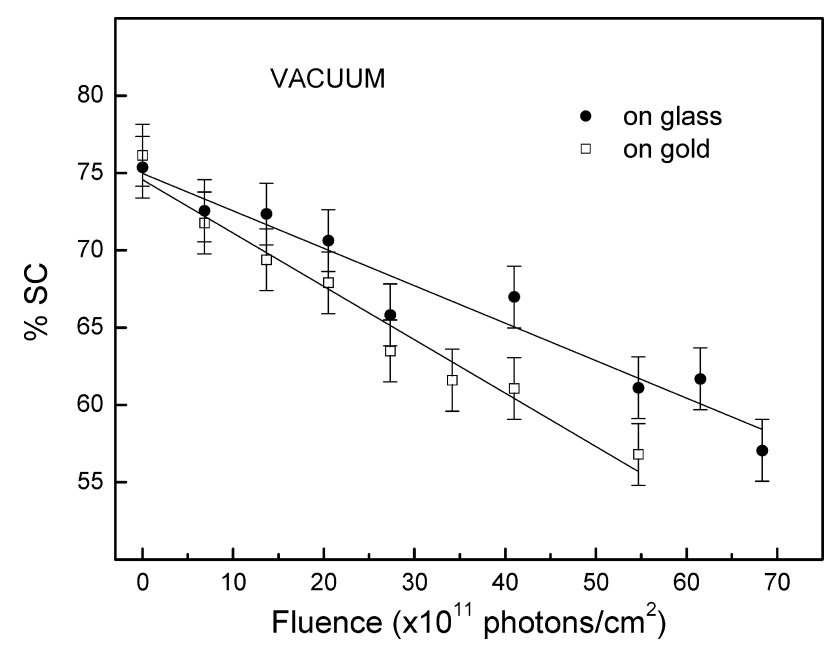

Figure 2. X-ray exposure curves for the loss of the supercoiled DNA in vacuum on glass and gold substrates. The points represent the means of three independent experiments and the error bars represent standard deviation of the means.

atmosphere) and the Perkin-Elmer X-ray source (in vacuum). Then, by comparison with the Perkin-Elmer source $\left(1.14 \times 10^{10}\right.$ photons $\left.\cdot \mathrm{cm}^{-2} \cdot \mathrm{s}^{-1}\right)$, the incident fluence rate of photons of the cold-cathode X-ray tube was estimated at $4.66 \times 10^{9}$ photons $\cdot \mathrm{cm}^{-2} \cdot \mathrm{s}^{-1}$.

DNA Damage Quantification by Agarose Gel Electrophoresis. After irradiation, DNA was immediately dissolved in $10 \mu \mathrm{L}$ of TE buffer. The different DNA plasmid forms were resolved by a $1 \%$ agarose gel electrophoresis run in TAE buffer (40 $\mathrm{mM}$ Tris acetate, $1 \mathrm{mM}$ EDTA, $\mathrm{pH} 8.0$ ) at $6.7 \mathrm{~V} \cdot \mathrm{cm}^{-1}$ for 90 min. Both gel and DNA were prestained by SYBR Green I (Molecular Probes), $1 \times$ for gel and $20 \times$ for samples. One hundred nanograms of DNA was loaded per well. After electrophoresis, gels were scanned with the STORM860 using blue fluorescence mode (Molecular Dynamics) at an excitation wavelength of $430 \mathrm{~nm}$. The relative amounts of each form of DNA were obtained from ImageJ analysis. To correct for the weaker binding of SYBR Green I to the supercoiled form of DNA compared with nicked circular and linear configurations, supercoiled DNA was digested by the EcoR1 enzyme in appropriate buffer at $37{ }^{\circ} \mathrm{C}$ during 45 min resulting in its linearization. Equal amounts of supercoiled and digested plasmid were loaded on an agarose gel and stained as usual. A factor of 1.2 was found between the areas under the peaks after ImageQuant quantification (Molecular Dynamics).

\section{Results}

Figure 2 shows the percentage loss of supercoiled DNA as a function of incident photon fluence (i.e., photons $\cdot \mathrm{cm}^{-2}$ ) in UHV for $5 \mathrm{ML}$ DNA films on glass and gold substrates. Within experimental error, the loss of the supercoiled form is a linear function of the photon fluence. The percentage yields derived from the slope of these curves are given in the first line of Table 1. The enhancement factors (EF) derived from these values appear on the right. The EF is calculated by dividing the yield obtained with the DNA on the gold substrate by that measured with pure DNA films. As expected, the gold substrate enhances DNA damage. An EF of 1.4 corresponds to a gain of $42 \%$ in DNA damage.

Figure 3 presents the dose-response curves for the same substrates under atmospheric conditions. The loss of supercoiled DNA is a linear function of fluence in both cases. The 
TABLE 1: Percentage Yield per $10^{12}$ photons $\cdot \mathrm{cm}^{-2}$ for the Loss of Supercoiled DNA in 5 ML Films Deposited on Glass and Gold Substrates and Held under Vacuum or Atmospheric Conditions ${ }^{a}$

\begin{tabular}{|c|c|c|c|c|c|}
\hline \multirow[b]{2}{*}{ environment } & \multicolumn{2}{|c|}{ substrate } & \multirow[b]{2}{*}{$\mathrm{EF}$} & \multirow[b]{2}{*}{$G_{\mathrm{L}}$} & \multirow[b]{2}{*}{$G_{\mathrm{X}}$} \\
\hline & glass & gold & & & \\
\hline vacuum (V) & $2.4 \pm 0.2$ & $3.4 \pm 0.3$ & 1.4 & $4 \pm 2$ & $0.42 \pm 0.04$ \\
\hline atmosphere (A) & $4.7 \pm 0.5$ & $8.7 \pm 0.9$ & 1.9 & $6 \pm 2$ & $0.40 \pm 0.04$ \\
\hline $\mathrm{A} / \mathrm{V}$ & 2.0 & 2.6 & & & \\
\hline
\end{tabular}

${ }^{a} G_{\mathrm{L}}$ and $G_{\mathrm{X}}$ are the $G$ values $(\mathrm{D} / 100 \mathrm{eV})$ for LEEs and X-rays, respectively.

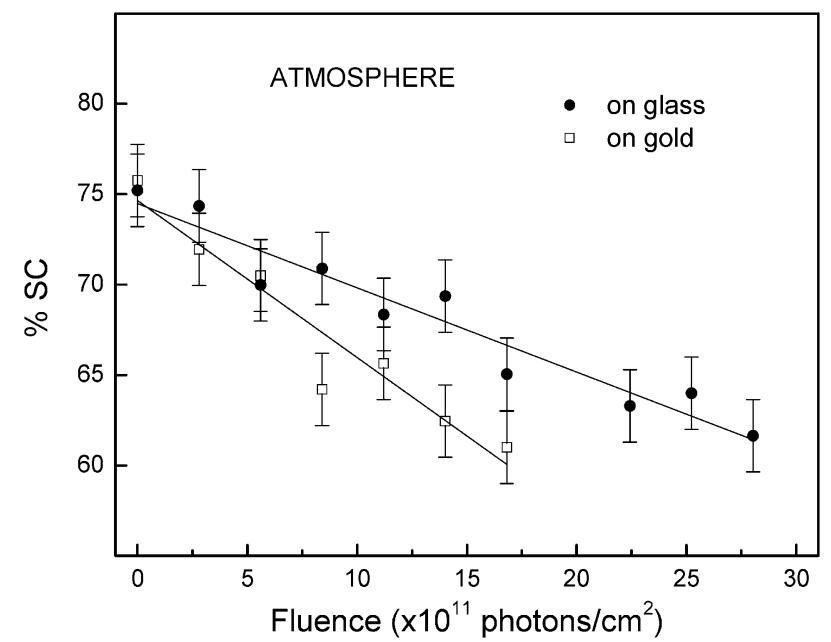

Figure 3. X-ray exposure curves for the loss of the supercoiled DNA under atmospheric conditions on glass and gold substrates. The points represent the means of three independent experiments and the error bars represent standard deviation of the means.

percentage yields derived from the slope of these curves are given in the second line of Table 1. The EF increases to 1.9 under atmosphere. From comparison of data under vacuum and atmosphere, gains of $96 \%$ and $156 \%$ are obtained with water for glass and gold substrates, respectively. As shown in the bottom line of Table 1, these percentages correspond to increases by factors of 2.0 and 2.6, respectively, compared with vacuum data.

The SE energy distribution emitted from the gold substrate, which is induced by $\mathrm{Al} \mathrm{K \alpha} \mathrm{X}$-rays, is shown in Figure 4. The 7-1486 eV distribution was measured with the X-ray photoelectron spectrometer housed in UHV. For $0-30 \mathrm{eV} \mathrm{SE}$, the energy distribution $\eta\left(E_{\mathrm{k}}\right)$ was calculated using ${ }^{33}$

$$
\eta\left(E_{\mathrm{k}}\right)=\eta_{\mathrm{s}} E_{\mathrm{k}} /\left(E_{\mathrm{k}}+W\right)^{4}
$$

where $\eta_{\mathrm{s}}$ is a coefficient that normalizes the yield of SEs having kinetic energy of $E_{\mathrm{k}}$ and $W$ is the work function of gold, that is, $4.8 \mathrm{eV} .^{34}$ The LEE distribution normalized to the one between 7 and $1486 \mathrm{eV}$ is shown in the inset of Figure 4. A typical measure of this distribution can be found in ref 35 . The LEE distribution has a peak at $1.4 \mathrm{eV}$ and a median energy of 4.0 $\mathrm{eV}$. Ninety-six percent of these SEs have energies below 30 $\mathrm{eV}$, and the average energy for these electrons is $5.9 \mathrm{eV}$. The total yield, $\eta(0-1486 \mathrm{eV})$, is derived to be 0.063 electron per photon. ${ }^{35}$ From these numbers and the spectra shown in Figure 4 , we assume in any further discussion that the damage caused by SEs emitted from the gold substrate arise principally from electrons of energies lower than $30 \mathrm{eV}$.

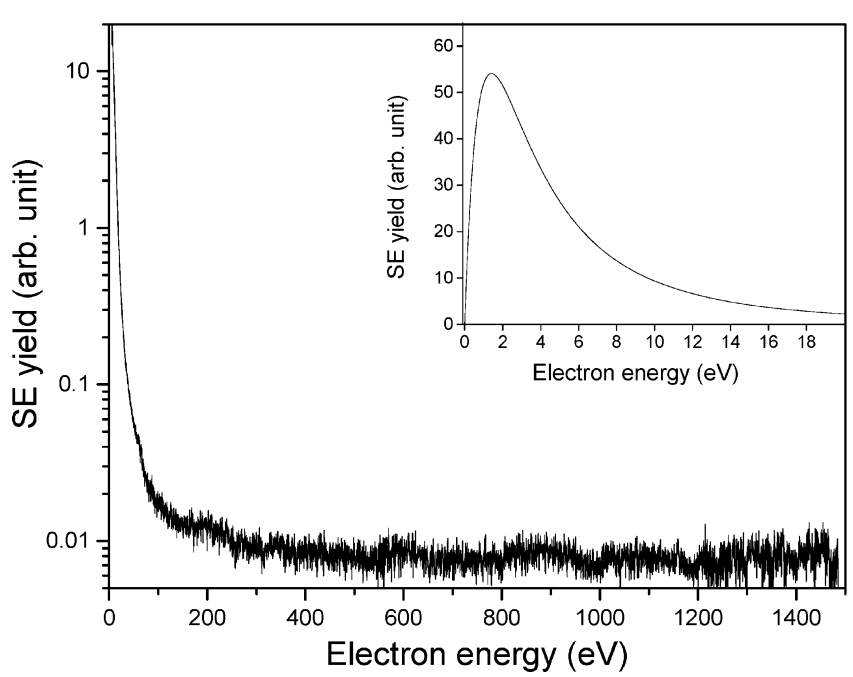

Figure 4. Energy spectrum of induced secondary electron emission from a gold surface.

\section{Discussion}

Given the mass absorption coefficient of $\mathrm{DNA}^{36}$ and the formula for transmitted photons ( $X_{\text {trans }}$ in the Supporting Information), one can calculate that within a $5 \mathrm{ML}$ film, $0.2 \%$ of $1.5 \mathrm{keV}$ photons interact with DNA, while the rest pass through DNA. Thus, with DNA lying on the gold substrate, $99.8 \%$ of the photons enter the metal foil and produce SEs. However only $6.3 \%$ of the photons in the foil produce a SE emitted from the surface. Hence, for one X-ray photon interacting with DNA, about 31 LEEs are emitted from the substrate. Since LEEs have an effective range on the order of the film thickness, most of these deposit their energy in DNA. We therefore interpret the difference in the yields of damage to DNA on glass and gold substrates as due to the additional energy deposited from LEEs emitted from the gold substrate. In the case of the vacuum experiments, if we assume that all the energy of the interacting photons is absorbed by the DNA and that all the energy of LEEs emitted from the gold surface is absorbed by the DNA multilayer, X-rays deposit about 8 times more energy in our films than SEs emitted from gold. Thus, DNA damage is induced by both X-ray photons and LEEs when DNA lies on a gold substrate.

With these two assumptions and the slopes of the curves of Figure 2, we estimate that the $G$ value for $1.5 \mathrm{keV} X$-rays in vacuum is $44 \pm 6 \mathrm{nmol} \cdot \mathrm{J}^{-1}(0.42 \mathrm{D} / 100 \mathrm{eV})$ and that of LEEs is $400 \pm 200 \mathrm{nmol} \cdot \mathrm{J}^{-1}(4 \mathrm{D} / 100 \mathrm{eV})$, where $\mathrm{D}$ represents one damaged DNA molecule. In the case of the atmospheric experiments, taking into account energy absorption by water molecules, we estimate from the slopes of Figure 3, $G$ values of $42 \pm 6 \mathrm{nmol} \cdot \mathrm{J}^{-1}(0.40 \mathrm{D} / 100 \mathrm{eV})$ for $1.5 \mathrm{keV} \mathrm{X}$-rays and $600 \pm 200 \mathrm{nmol} \cdot \mathrm{J}^{-1}(6 \mathrm{D} / 100 \mathrm{eV})$ for LEEs. Details of the calculations are provided in the Supporting Information. Since the interaction of $\mathrm{Al} \mathrm{K} \alpha \mathrm{X}$-rays with DNA is mainly via the photoelectric effect, it results in photoelectrons and Auger electrons, having energies of 960 and $520 \mathrm{eV}^{22}$ and an axial penetration of about 18 and $8 \mathrm{~nm},{ }^{37}$ respectively. Even photoelectrons and Auger electrons produced in the middle of the 10 $\mathrm{nm}$ films would be transmitted through the $5 \mathrm{~nm}$ in the layer of DNA. Thus, many of the photoelectrons and Auger electrons can escape into vacuum or in the gold substrate and not deposit all of their energies in the film. Hence the above assumptions probably underestimate the $G$ values for X-rays. Nevertheless, the $G$ values for X-rays measured here with a $5 \mathrm{ML}$ film of DNA are close to that of $57 \pm 1$ measured in the same apparatus 
by Cai et al. ${ }^{38}$ for a thick $20 \mathrm{~mm}$ film of DNA in which essentially all of the X-ray energy was deposited. Other $G$ values obtained for DNA films by $0.4-2 \mathrm{keV}$ X-rays are in good agreement with those shown in Table 1 but usually higher. ${ }^{16,39-43}$ The $G$ values for LEEs in vacuum can only be compared with that determined by Cai et al., ${ }^{38}$ who found an average $G$ of 164 $\mathrm{nmol} \cdot \mathrm{J}^{-1}$ in the case of monolayer DNA films condensed on tantalum in vacuum. Our corresponding value is about 2.4 times larger than that measured by Cai et al. This difference is probably due to the different film thickness in the two experiments. With only one monolayer of DNA, LEEs can escape in vacuum or in the substrate without depositing all of their energy, but Cai et al. assume all the energy of the lowenergy photoelectrons to have been deposited in their singlelayer DNA film. From the known attenuation lengths of LEEs in single-strand DNA, ${ }^{44}$ this 2.4 factor appears reasonable. It should be noted, however, that the DNA in contact with the metal substrate may be chemically sensitized to the damage induced by both X-rays and photoelectrons. $G$ values for LEE impact on 5 ML films of DNA should therefore be considered more reliable because essentially all LEEs lose their energy in such films and most of the DNA is not sensitized by the metal interface. As in the work of Cai et al., ${ }^{38}$ it is clear from the deduced $G$ values that SE are more efficient than X-ray photons to induce DNA damage. In other words, when the same amount of energy is deposited in DNA by photons and low-energy SE, the latter produce much more damage. In the presence of water, the $G$ value of LEEs further increases by $50 \%$ whereas that of $\mathrm{X}$-rays remains the same within instrumental error.

There are a number of mechanisms that can account for the differences between $G$ values for X-rays and LEEs, although the details cannot be determined exactly at this stage. In the case of $\mathrm{Al} \mathrm{K} \alpha \mathrm{X}$-rays, photoelectrons and Auger electrons react essentially via the emission of virtual photons, ${ }^{45}$ so as to deposit in organic matter about $20 \%$ of their energy into vibrational and electronic excitation and $80 \%$ into ionization. ${ }^{46}$ Thus, a large portion of the energy deposited by X-rays flows into the creation of an ion or a hole and of SEs with a wide energy distribution centered around $10 \mathrm{eV} .^{6}$ Whereas X-rays and fast electrons produce electronic and vibrational excitation in a similar proportion, the relative abundance of electronic excitations may be much larger for LEEs due to the formation of transient anions. Such a difference results in a higher number of dissociative states produced per unit energy deposited by LEEs. Also, due to charge polarization and the formation of transient anions, it takes less energy to break a chemical bond with a LEE than with a photon. The threshold energy for breaking a DNA strand with a photon lies around $7 \mathrm{eV},{ }^{47}$ whereas a LEE induces a SSB in DNA by dissociative electron attachment (DEA) via shape resonances located at 0.8 and $2.3 \mathrm{eV} .{ }^{48}$ Coreexcited resonances induce SSB and $\mathrm{DSB}^{49-52}$ from 5 to $15 \mathrm{eV}$ with an efficiency as large as at $100 \mathrm{eV}$. The cross section to produce a SSB in DNA via DEA is on the order of $2 \times 10^{-18}$ $\mathrm{cm}^{2}$ and similar at $0.8 \mathrm{eV}$ and around $10 \mathrm{eV},{ }^{53}$ suggesting that low-lying shape resonances and core-excited resonances in DNA are highly efficient for breaking the phosphodiester backbone. Thus, SEs emitted from gold with an energy distribution peaking around $1.4 \mathrm{eV}$ can cause considerable DNA damage via DEA. In other words, the dissociative processes are triggered with much less energy with LEEs giving higher $G$ values.

According to the results of the first column of numbers in Table 1, adding the hydration layers and oxygen around DNA, while keeping all other experimental parameters the same, increases radiation damage by about a factor of 2 . This result is in good agreement with recent estimates of the relative contribution to DNA damage in cells via the direct and indirect effects of radiation. Von Sonntag has estimated that the direct effects contribute about $40 \%$ to cellular DNA damage, while the effects of water radicals amount to about $60 \% .{ }^{54}$ The work of Krisch et al. on the production of strand breaks in DNA initiated by $\mathrm{HO}^{\circ}$ radical attack sets the direct effects contribution at $50 \% .{ }^{55}$ From the experiments of de Lara et al., one can estimate that $40-50 \%$ of the lesions induced in DNA by low linear energy transfer radiation arise from direct energy deposition events, many of which ionize DNA. ${ }^{56}$ In other words, if we assume that the direct effects of radiation in cells corresponds to the damage we measure in vacuum with X-rays, we also deduce from Table 1 a $50 \%$ contribution of the indirect effect (i.e., that caused by the presence of water molecules).

In dilute solution of DNA, the hydroxyl radical $\left(\mathrm{OH}^{\circ}\right)$ is considered to be the secondary species formed by water radiolysis that produces the largest amount of DNA damage. However, since in our films, contrary to a dilute solution of DNA, the number of $\mathrm{H}_{2} \mathrm{O}$ molecules is limited to about 20 per nucleotide and resides in close contract with DNA, we would like to mention that electron and hole transfer from water to DNA may also play a role in the mechanism of damage under atmospheric conditions.

With DNA deposited on the gold substrate, adding the hydration layer leads to a larger increase in DNA damage; that is, the yield of the loss of the supercoiled configuration is increased by a factor of 2.6 compared with 2.0 on glass. Since the gold substrate increases considerably the density of LEEs in the DNA film, the latter result implies that the interaction of these electrons with $\mathrm{H}_{2} \mathrm{O}$ produces species that highly efficiently damage DNA.

Fragmentation of condensed-phase $\mathrm{H}_{2} \mathrm{O}$ by LEE impact has been investigated mainly with amorphous ice films. The yield function for desorption of $\mathrm{H}^{-},{ }^{57-59} \mathrm{H}_{2},{ }^{60,61} \mathrm{D}\left({ }^{2} \mathrm{~S}\right), \mathrm{O}\left({ }^{3} \mathrm{P}\right)$, and $\mathrm{O}\left({ }^{1} \mathrm{D}_{2}\right)^{62,63}$ were recorded in the range $5-30 \mathrm{eV}$. Most of these functions exhibit resonance structures below $15 \mathrm{eV}$, which are characteristic of transient anion formation. From anion yields, DEA to condensed $\mathrm{H}_{2} \mathrm{O}$ was shown to result principally in the formation of $\mathrm{H}^{-}$and the $\mathrm{HO}^{\bullet}$ radical from dissociation of the ${ }^{2} \mathrm{~B}_{1}$ state of $\mathrm{H}_{2} \mathrm{O}^{-}$located in the $7-9 \mathrm{eV}$ region. Smaller contributions arise from the ${ }^{2} \mathrm{~A}_{1}$ and ${ }^{2} \mathrm{~B}_{2}$ anionic states, which are formed near 9 and $11 \mathrm{eV}$, respectively. ${ }^{57,58}$ At higher energies, nonresonant processes, such as dipolar dissociation lead to $\mathrm{H}_{2} \mathrm{O}$ fragmentation with the assistance of a broad resonance that extends from 20 to $30 \mathrm{eV}{ }^{58}$ Kimmel et al. measured the $\mathrm{D}_{2}\left(\mathrm{X}^{1} \sum_{\mathrm{g}}^{+}\right), \mathrm{D}\left({ }^{2} \mathrm{~S}\right), \mathrm{O}\left({ }^{3} \mathrm{P}_{j=2,1,0}\right)$, and $\mathrm{O}\left({ }^{1} \mathrm{D}_{2}\right)$ products ${ }^{62,63}$ that desorb from amorphous ice. The $\mathrm{D}\left({ }^{2} \mathrm{~S}\right), \mathrm{O}\left({ }^{3} \mathrm{P}_{2}\right)$, and $\mathrm{O}\left({ }^{1} \mathrm{D}_{2}\right)$ yields versus incident electron energy have an apparent threshold at $\sim 6.5 \mathrm{eV}$ with a steadily increasing intensity. Above this threshold, the $\mathrm{D}\left({ }^{2} \mathrm{~S}\right)$ intensity also increases rapidly and exhibits a broad resonance for $\sim 14-21 \mathrm{eV}$. Above $7 \mathrm{eV}$, direct electronic excitation of the ${ }^{3,1} \mathrm{~B}$ states lead to $\mathrm{H}^{\circ}$ and $\mathrm{HO}^{\circ}$ formation. From $10 \mathrm{eV}$, ionization progressively takes over and dominates energy losses. The ensemble of these reactions leads to an abundant production of $\mathrm{OH}$ and $\mathrm{H}$ radicals and $\mathrm{H}_{2}$ molecules. Within the energy range of electrons emitted from the gold substrate $(0-30 \mathrm{eV})$, the cross sections for excitation of the electronic states leading to $\mathrm{HO}^{\circ}, \mathrm{H}^{\bullet}$ and $\mathrm{H}_{2}$ production varies from $10^{-19}$ to about $10^{-17} \mathrm{~cm}^{2}$ in amorphous ice. ${ }^{64}$ These values compare with similar cross sections of $(1-3) \times 10^{-18}$ $\mathrm{cm}^{2}$ per nucleotide for inducing strand breaks in DNA with LEEs. ${ }^{53}$ However, since in hydrated DNA, there are about 20 water molecules per nucleotide, the probability of producing 
$\mathrm{OH}$ and $\mathrm{H}$ radicals becomes higher than that of directly damaging DNA. This propensity toward radical formation from $\mathrm{H}_{2} \mathrm{O}$ by LEEs in hydrated DNA may account for the large increase by a factor of 2.6 in damage to DNA deposited on the gold substrate.

\section{Conclusion}

We have shown that photoelectrons emitted from a gold substrate can be used as a source of low-energy electrons (LEEs) to irradiate DNA films under atmospheric conditions. LEE damage to plasmid DNA with its hydratation shell was measured from comparison of results obtained with films deposited on gold and glass substrates. The technique allowed $G$ values to be obtained for the direct and indirect effects of LEEs on DNA damage.

Acknowledgment. We thank Ariane Dumont for providing us with the plasmid. This work was supported by the Canadian Institutes of Health Research (CIHR) and the Centre National de la Recherche Scientifique (CNRS).

Supporting Information Available: Details about of the calculations of the $G$ values for photons and low-energy electrons. This material is available free of charge via the Internet at http://pubs.acs.org.

\section{References and Notes}

(1) Sanche, L. Low-energy electron damage to DNA. In Radiation Induced Molecular Phenomena in Nucleic Acids; Shukla, M. K., Leszczynski, J., Eds.; Springer: Dordrecht, Netherlands, 2008; p 531.

(2) Rak, J.; Mazurkiewicz, K.; Kobylecka, M.; Storoniak, P.; Haranczyk, M.; Dabkowska, I.; Bachorz, R. A.; Gutowski, M.; Radisic, D.; Stokes, S. T.; Eustis, S. N.; Wang, D.; Li, X.; Ko, Y. J.; Bowen, K. H. Stable valence anions of nucleic acid bases and DNA strand breaks induced by low energy electrons. In Radiation Induced Molecular Phenomena in Nucleic Acids; Shukla, M. K., Leszczynski, J., Eds.; Springer: Dordrecht, Netherlands, 2008; p 619.

(3) Kumar, A.; Sevilla, M. D. Radiation effects on DNA: Theoretical investigations of electron, hole and excitation pathways to DNA damage. In Radiation Induced Molecular Phenomena in Nucleic Acids; Shukla, M. K.; Leszczynski, J., Eds.; Springer: Dordrecht, Netherlands, 2008; p 577.

(4) Sanche, L. Mass. Spectrom. Rev. 2002, 21, 349.

(5) Sanche, L.; Märk, T. D.; Hatano, Y. Low-energy electron interactions with condensed matter. In Atomic and Molecular Data Needed for Radiotherapy, TECDOC-799; Inokuti, M. Ed.; IAEA Press: Vienna, 1995

(6) Pimblott, S. M.; LaVerne, J. A. Radiat. Phys. Chem. 2007, 76, 1244

(7) Moretto-Capelle, P.; Le Padellec, A. Phys. Rev. A 2006, 74, 062705.

(8) Sanche, L. Eur. Phys. J. D 2005, 35, 367.

(9) Denifl, S.; Zappa, F.; Mähr, I.; Lecointre, J.; Probst, M.; Märk, T. D.; Scheier, P. Phys. Rev. Lett. 2006, 97, 043201.

(10) Yamamoto, O. Aging, Carcinogenesis and Radiation Biology; Plenum: New York, 1976.

(11) Adams, R. L. P.; Knowler, J. T.; Leader, D. P. The biochemistry of the nucleic acids, 10th ed.; Chapman and Hall: New York, 1986.

(12) Saenger, W. Annu. Rev. Biophys. Biophys. Chem. 1987, 16, 93.

(13) Tao, N. J.; Lindsay, S. M.; Rupprecht, A. Biopolymers 1989, 28, 1019.

(14) Debije, M. G.; Strickler, M. D.; Bernhard, W. A. Radiat. Res. 2000, 154,163 . 673

(15) La Vere, T.; Becker, D.; Sevilla, M. D. Radiat. Res. 1996, 145,

(16) Yokoya, A.; Cunniffe, S. M.; O’Neill, P. J. Am. Chem. Soc. 2002, 124,8859 .

(17) Swarts, S. G.; Sevilla, M. D.; Becker, D.; Tokar, C. J.; Wheeler, K. T. Radiat. Res. 1992, 129, 333.

(18) Swarts, S. G.; Becker, D.; Sevilla, M. D.; Wheeler, K. T. Radiat. Res. 1996, 141, 304.

(19) Falcone, J. M.; Becker, D.; Sevilla, M. D.; Swarts, S. G. Radiat. Phys. Chem. 2005, 72, 257.

(20) Eschenbrenner, A.; Herve Du Penhoat, M. A.; Boissiere, A.; EotHoullier, G.; Abel, F.; Politis, M. F.; Touati, A.; Sage, E.; Chetioui, A. Int J. Radiat. Biol. 2007, 83, 687 .
(21) Cai, Z.; Cloutier, P.; Hunting, D.; Sanche, L. Radiat. Res. 2006, 165,365 .

(22) Goodhead, D. T.; Thacker, J. Int. J. Radiat. Biol. 1977, 31, 541.

(23) Hoshi, M.; Goodhead, D. T.; Brenner, D. J.; Bance, D. A.; Chmielewski, J. J.; Paciotti, M. A.; Bradbury, J. N. Phys. Med. Biol. 1985, $30,1029$.

(24) Neary, G. J.; Savage, J. R.; Evans, H. J. Int. J. Radiat. Biol. Relat. Stud. Phys. Chem. Med. 1964, 8, 1.

(25) Sambrook, R. Molecular Cloning. A Laboratory Manual, 3rd ed.; Cold Spring Harbor Laboratory Press: New York, 2001.

(26) Manchester, K. L. Biotechniques 1996, 20, 968.

(27) Manchester, K. L. Biotechniques 1995, 19, 208.

(28) Glasel, J. A. Biotechniques 1995, 18, 62.

(29) Wilfinger, W. W.; Mackey, K.; Chomczynski, P. Biotechniques 1997, 22, 474

(30) Ptasinska, S.; Sanche, L. J. Chem. Phys. 2006, 125, 144713.

(31) Cai, Z.; Pan, X.; Hunting, D.; Cloutier, P.; Lemay, R.; Sanche, L. Phys. Med. Biol. 2003, 48, 4111.

(32) Abramoff, M. D.; Magelhaes, P. J.; Ram, S. J. Biophoton. Int. 2004, $11,36$.

(33) Henke, B. L.; Smith, J. A. J. Appl. Phys. 1977, 48, 1852.

(34) Anderson, P. A. Phys. Rev. 1959, 1115, 553.

(35) Henke, B. L.; Liesegang, J.; Smith, S. D. Phys. Rev. B 1979, 19, 3004 .

(36) http://physics.nist.gov/PhysRefData/XrayMassCoef/.

(37) Pimblott, S. M.; Siebbeles, L. D. A. Nucl. Instrum. Methods Phys. Res., Sect. B 2002, 194, 237.

(38) Cai, Z.; Cloutier, P.; Hunting, D.; Sanche, L. J. Phys. Chem. B 2005, 109, 4796.

(39) Ito, T.; Baker, S. C.; Stickley, C. D.; Peak, J. G.; Peak, M. J. Int. J. Radiat. Biol. 1993, 63, 289.

(40) Hieda, K.; Hirono, T.; Azami, A.; Suzuki, M.; Furusawa, Y.; Maezawa, H.; Usami, N.; Yokoya, A.; Kobayashi, K. Int. J. Radiat. Biol. 1996, 70, 437.

(41) Fayard, B.; Touati, A.; Sage, E.; Abel, F.; Champion, C.; Chetoui, A. J. Chim. Phys. Phys.-Chim. Biol. 1999, 96, 147.

(42) Yokoya, A.; Watanabe, R.; Hara, T. J. Radiat. Res. (Tokyo) 1999, $40,145$.

(43) Razskazovskiy, Y.; Debije, M. G.; Bernhard, W. A. Radiat. Res. 2003, 159, 663 .

(44) Cai, Z.; Dextraze, M. E.; Cloutier, P.; Hunting, D.; Sanche, L. J. Chem. Phys. 2006, 124, 024705.

(45) Shimamura, J.; Takayanagi, K. Electron-molecule collision; Plenum: New York, 1984.

(46) Inotuki, M. Atomic and molecular data needed for radiotherapy and radiation research; TECHDOC-799, IAEA Press: Vienna, 1995.

(47) Folkard, M.; Prise, K. M.; Vojnovic, B.; Brocklehurst, B.; Michael,

B. D. Int. J. Radiat. Biol. 2000, 76, 763.

(48) Martin, F.; Burrow, P. D.; Cai, Z.; Cloutier, P.; Hunting, D.; Sanche, L. Phys. Rev. Lett. 2004, 93, 068101.

(49) Boudaiffa, B.; Cloutier, P.; Hunting, D.; Huels, M. A.; Sanche, L. Science 2000, 287, 1658.

(50) Boudaiffa, B.; Cloutier, P.; Hunting, D.; Huels, M. A.; Sanche, L. Radiat. Res. 2002, 157, 227.

(51) Huels, M. A.; Boudaiffa, B.; Cloutier, P.; Hunting, D.; Sanche, L. J. Am. Chem. Soc. 2003, 125, 4467.

(52) Pan, X.; Cloutier, P.; Hunting, D.; Sanche, L. Phys. Rev. Lett. 2003, 90, 208102.

(53) Panajotovic, R.; Martin, F.; Cloutier, P.; Hunting, D.; Sanche, L. Radiat. Res. 2006, 165, 452.

(54) Von Sonntag, C. The chemical basis of radiation biology; Taylor and Francis: London, New York, Philadelphia, 1987.

(55) Krisch, R. E.; Flick, M. B.; Trumbore, C. N. Radiat. Res. 1991, $126,251$.

(56) deLara, C. M.; Jenner, T. J.; Townsend, K. M. S.; Marsden, S. J.; O'Neill, P. Radiat. Res. 1995, 144, 43.

(57) Rowntree, P.; Parenteau, L.; Sanche, L. J. Chem. Phys. 1991, 94, 8570

(58) Simpson, W. C.; Sieger, M. T.; Orlando, T. M.; Parenteau, L.; Nagesha, K.; Sanche, L. J. Chem. Phys. 1997, 107, 8668.

(59) Simpson, W. C.; Orlando, T. M.; Parenteau, L.; Nagesha, K.; Sanche, L. J. Chem. Phys. 1998, 108, 5027.

(60) Kimmel, G. A.; Orlando, T. M. Phys. Rev. Lett. 1996, 77, 3983. (61) Kimmel, G. A.; Orlando, T. M.; Vezina, C.; Sanche, L. J. Chem.

Phys. 1994, 101, 3282.

(62) Kimmel, G. A.; Orlando, T. M. Phys. Rev. Lett. 1995, 75, 2606.

(63) Kimmel, G. A.; Orlando, T. M.; Cloutier, P.; Sanche, L. J. Phys. Chem. B 1997, 101, 6301.

(64) Michaud, M.; Wen, A.; Sanche, L. Radiat. Res. 2003, 159, 3.

JP902540K 